\title{
Diagnosis of subclinical mastitis in dairy goats (Review)
}

\author{
Dimiter Dimitrov ${ }^{1}$, Georgi Stoimenov ${ }^{1}$, \\ Oliver Morrison ${ }^{2}$
}

1. University of Forestry, Faculty of Veterinary Medicine, Sofia, 1000, Bulgaria;

2. Meadows Farm Vets Ltd. Stoke Prior, Bromsgrove, WORCESTERSHIRE, B60 4BH United Kingdom;

\begin{abstract}
Mastitis is a disease of the mammary gland that negatively influences the quantitative and qualitative parameters of milk. At the same time the milk from a mastitic gland is a source of infection to both other animals and the consumer and therefore a direct threat to human and animal health. This determines the importance of an early and accurate diagnosis of the various forms of inflammation of the mammary gland in goats. Clinical signs, measurement of somatic cells in milk and bacteriological examination are standard methods for diagnosis of mastitis. Bacteriology is not suitable as a routine first line test to identify subclinical mastitis. Therefore, indirect tests for the diagnosis of mastitis are more suitable for application in practice, and based on their results, samples can be selected for further examination. The purpose of this article is to look at the different test available for the diagnosis of subclinical mastitis in goats, based on various indicators of inflammation in the mammary gland.
\end{abstract}

\section{Keywords: mastitis, goats, mammary gland, diagnosis}

\section{Introduction}

Intra-mammary infections in small ruminants are mainly caused by bacteria. The most frequently isolated pathogens are coagulase - negative Staphylococcus spp. (McDougall et al., 2010, Hristov et al., 2016). For correct mastitis diagnosis in goats some specific physiological features must be kept in mind. In goats 
there is a short or sometimes absent dry period and varying somatic cell counts (SCC) as a response to other diseases and conditions. This phenomenon is described as a `stress sensitivity of the mammary gland.

Prevalence of subclinical mastitis in dairy goats varies between 5 and $45 \%$ (Contreras et al., 2007; Hristov et al., 2015). The difference between clinical and subclinical mastitis is the presence or absence of external inflammation. Therefore, subclinical forms require a broad spectrum of diagnostic techniques both on farm and in the laboratory. The diagnosis of subclinical mastitis is based on the presence of inflammatory markers in the milk and microbiological isolation of the causative agent. Mastitis leads to milk SCC changes as well as changes in physical and chemical characteristics of milk (Hristov et al., 2015). The grade of those changes depends on causative agent and the mammary tissue affected. The changes are mostly: ion, protein and enzyme flux from blood in to the milk, as a result of increased blood vessel permeability. As well as the inflammation there is also an increase in phagocytic activity and decreases in some other contents of the milk. The affected inflamed tissue produces specific inflammatory metabolites - acute phase proteins, which can be also used as an indicator of the inflammatory process in the udder.

\section{Review Results}

\section{Somatic Cell Count (SCC)}

SCC is a proven tool in subclinical mastitis diagnosis in dairy cattle. Its use in goats is still not widely recognized as a standard diagnostic test, because of the biological specifics of these animals. There are many factors that influence the SCC without an inflammatory reaction. These include: lactation stage, oestrus, breed, milking procedures etc. Therefore, exact reference levels are still not specified for SCC in goat's milk with respect to mastitis monitoring and diagnosis. In his study Borgonier et al., (2003) found SCC from $1.2 \times 106 / \mathrm{ml}$ to $1.6 \times 106 / \mathrm{ml}$ in bulk tank samples from Spain, France and Italy over a 5 year period. Souza et al., (2009) examined more than 1400 goats and found an average SCC of $779 \times 103 / \mathrm{ml}$. But Wilson et al., (1995) state that the SCC in goats can exceed 10 million in $1 \mathrm{ml}$. In the EU there is still not one accepted reference range for SCC in goats. This is why field examinations are still undertaken.

Vasiu et al., (2008) suggest using a threshold SCC of $500 \times 103 / \mathrm{ml}$, to distinguish infection from normal physiological levels. $75 \%$ of the samples examined had an SCC lower than $500 \times 103 / \mathrm{ml}$ and were assumed to have healthy udders, 6-11\% had mild infections with a mild SCC increase and $2 \%$ had an infection caused by highly pathogenic bacteria causing significant SCC increase in the milk sample. In the last field examination in Bulgaria using the same level of $500 \times 103 / \mathrm{ml}$ SCC Hristov (2015) successfully diagnosed subclinical cases of mastitis in dairy goat herds. Bozhkova et al., (2003) had similar results. She describes SCC in Bulgarian dairy goats with healthy mammary glands as being $500 \times 103 / \mathrm{ml}$, whereas in subclinical mastitis cases the SCC level is above $400 \times 104 / \mathrm{ml}$.

\section{Rapid mastitis test / California mastitis test (CMT)}

CMT is based on disrupting the membranes of somatic cells and the reaction of their DNA with an ionic surfactant. This reaction leads to changes in the milk viscosity so the higher the cell content - the higher the viscosity change. This is how the CMT gives an indication of the somatic cells in 
the milk sample (Schaeren and Maurer, 2006). However, the requirement for this test does not take into account all the circumstances under which the SCC can be increased. It is widely accepted to score the CMT result from 1 to 3 . Contreras et al., (2007) found $79 \%$ of scores $0-1$ represented uninfected halves, and a score of 2- 3 represented suspected infection of the half, requiring sampling for bacteriology. Comparison of the CMT results from both halves assists the subclinical mastitis diagnosis, because in those cases one of the halves has a score higher than 1 unit compared to the healthy one. According to Boscos et al., (2006) in $89 \%$ of the samples with Staph. aureus isolates, the CMT score was 2 points higher which implies that the score itself could be used as diagnostic tool to specify causative agent.

McDougall et al., (2010) examined the CMT sensitivity and specificity in relation to subclinical mastitis. They confirmed that in cases of subclinical mastitis there is a positive correlation between increased SCC, CMT score and current infection. Their final conclusion was that as the CMT score increases, the sensitivity and specificity also increase for diagnosis of subclinical mastitis cases. The represented references show that CMT results cannot be used as single diagnostic tool in subclinical mastitis but are very useful in a screening examination and selection of the animals for microbiology examination.

\section{Electrical conductivity}

The changes in blood vessel permeability in inflammatory cases leads to sodium and chloride ion increases in the milk, and subsequent electrical conductivity changes. The use of milk electrical conductivity is not widely used yet in dairy goat practice, although it is regularly assessed in the milk samples of dairy cattle. The reason for that is the absence of research and evidence in goat practice. Significant correlation between electrical conductivity and SCC as has been established in cow`s milk have not been described in goats (Park, 1991). Shupper et Schwope (1999) present results for goat's milk electrical conductivity. In their study they record average values of $6.6 \pm 0.5$ $\mathrm{mS} / \mathrm{cm} 3$. These results are confirmed by Baulbua (2009), who found values of $6.6 \pm 0.76$ $\mathrm{mS} / \mathrm{cm} 3$. Despite these findings, there are no universally accepted reliable values which can be applied in practice, and are still to be developed.

\section{4. $\mathbf{N}$-acetyl - $\beta-D-$ Glucosaminidase (NAGase)}

In both clinical and subclinical mastitis, the number of polymorphonuclear cells and macrophages are increased as a response to inflammation. Inflammation increases the concentration of some hydrolytic enzymes like NAGase and $\beta$-glucoronidase, which are normally stored in lysosomes. Another non-lysosomic enzyme that also increases is lactate dehydrogenase.

Maisi and Ripinen (1988) suggest that NAGase measurement can be applied to the diagnosis of subclinical mastitis although its concentration is 4 times lower than in cow's milk. In a study by Vihan (1989), the levels of NAGase and SCC in healthy and infected halves were measured. He found that NAGase is significantly higher in cases of mastitis caused by coagulase-negative Staphylococci and Mycoplasma agents. The author explains the differences in enzyme concentration by the presence of epithelial plasma residues in the infected halves.

Maisi (1990) notes that NAGase in the infected halves is $10.3 \pm 6.3 \mathrm{IU}$, whereas the level in unaffected halves is $0.9 \pm 1.5 \mathrm{IU}$. Along with this he also records that enzyme activity increases in both affected and healthy halves in the same examined udder. The same author also notes the relationship between NAGase and lactation stage, in which the enzyme activity is increased in the 
first week and after 270 DIM. There is also a recognized difference in the age of animal and enzymes levels with these being lowest in the first lactation. Despite these variations NAGase could be used as a diagnostic characteristic of the mastitic gland. Litner (2004) found infected halves with levels of $59.2 \pm 5.3 \mathrm{IU}$ and $15.6 \pm 0.8 \mathrm{IU}$ in unaffected halves. The same author recommends the level of NAGase can be used in subclinical mastitis diagnosis up to 130 DIM, but not immediately after kidding due to the potential physiological increase in SCC. Bartha et al., (2010) also confirm the presence of a significantly high positive correlation between NAGase, SCC and lactoferrin level and advised the use of the enzyme for diagnosis.

\section{5. $\boldsymbol{\beta}$-glucoronidase}

$\beta$ - glucoronidase is a lysosomic enzyme released in inflammation. The use of this enzyme as a diagnostic tool has been developed for large animals. A study by Oliszewski et al., (2002) looking at mastitis in small ruminants supplies a lot of information. They compare the results of $\beta$ glucoronidase tests, SCC and CMT score. They find that in 79 of 124 samples the level of SCC is less than $1.3 \times 103 / \mathrm{ml}$, at the same time $93 \%$ of them have low levels of $\beta$ - glucoronidase activity $(\square 15 \mathrm{IU} / \mathrm{ml}$ ). In the remaining samples with SCC above $1.3 \times 103 / \mathrm{ml}, 88 \%$ show high levels of the enzyme activity (> $15 \mathrm{U} / \mathrm{ml}$ ). Larsen et Aulrich (2012) suggest using an optimized fluorimetric method for the exact measurement of $\beta$ - glucoronidase activity in ruminant milk and its applicability together with other indicators of mastitis. They confirm the reliability of the test together with CMT and SCC, but more research is needed to apply $\beta$ - glucoronidase activity by itself in practice.

\section{Lactoferrin (LF)}

The lactoferrin is an iron-binding cation glycoprotein from the transferrin family. It is present in a variety of animal tissues as a non-specific immune factor. It has antimicrobial activity against bacteria, fungi and some viruses (Van der Strate et al., 2001). It has been proven that lactoferrin activity can be protective of some neoplasia's and their metastases (Pierce and Legrand, 2009) In their study Chen et al., (2004) found that in premium quality milk the lactoferrin (LF) level is 167 $\mathrm{mg} / \mathrm{ml}$, in average quality $218 \mathrm{mg} / \mathrm{ml}$, and when milk has changed quality indicators the LF level is $304 \mathrm{mg} / \mathrm{ml}$. In milk from mastitic halves the LF level is increased and can reach value of 587 $\mathrm{mg} / \mathrm{ml}$. Based on all these examinations the authors conclude that with the presence of infection the LF level is significantly increased and can serve as indicator for mastitis diagnosis. Bartha et al., (2010) examined the influence of inflammation on SCC, NAGase and LF. As a result, they found significant correlation in the changes of those inflammatory indicators, but LF is the most significant when confirming inflammation in infected halves. They also found that in the first lactation, LF concentration is significantly higher compared to animals in subsequent lactations.

\section{Conclusion}

The presented data from the analysis of the cited authors shows that the inflammatory reaction in the milk glandular tissue leads to changes in concentration of SCC, LF and $\beta$-glucoronidase.

A promising approach for early subclinical mastitis detection could be a combination of SCC, LF and NAGase, keeping in mind that some physiological features can influence their values. 
As LF is not affected by the season or lactation stage it can be used to diagnose mastitis at any stage of the reproductive cycle.

\section{References}

1. Bartha, K., K. Aulricha, U. Muller et al., Somatic cell count, lactoferrin and NAGase activity in milk of infected and non-infected udder halves of dairy goats. Small Ruminant Research 94, 161-166, 2010

2. Bergonier D., De Cremoux R, Rupp R et al., Mastitis of dairy small ruminants. Vet Res 34:689716, 2003

3. Boscos C., Stefanakis A., Alexopoulos C et al., Prevalence of subcli-nical mastitis and influence of breed, parity, stage of lactation and mamma $\neg$ ry bacteriological status on Coulter Counter Counts and California Mastitis Test in the milk of Saanen and autochthonous Greek goats. Small Rumin Res 21:139-147, 1996

4. Boulaaba A., Contributions to understand caprine udder health and flow cytometric differentiation of caprine milk cells. Thesis, Gießen, p. 285, 2009

5. Bozhkova, G., T. Glbinova, N. Korudžijski et al., Cytological and biochemical changes in goat milk with subclinical mastitis. Bulgarian Journal of Animal Husbandry, 5, 99-102, 2003.

6. Chen, P.W., Chen, W.C., Mao, F.C., Increase of lactoferrin concentration in Mastitic goat milk. Vet. Med. Sci. 66, 345-350, 2004.

7. Contreras, A., D. Sierra, A. Sanchez et al.. Mastitis in small ruminants. Small Rumin. Res. 68:145-153, 2007.

8. Haenlein G. F.W., Relationship of somatic cell counts in goat milk to masti-tis and productivity. Small Rumin Res 45:163-178, 2002

9. Hristov K., Parvanov P., Pepovich R., Nikolov B., Prevalence of mastitis and dynamics of health status mammary gland during lactation and dry period in goats. Scientific Works. Series C. Veterinary Medicine. Vol. LXI (1); 163 - 167, 2015.

10. Hristov K., Prevalence and innovative aspects of etiology, diagnosis and prevention of mastitis in goats. Dissertation, Sofia, p.173, 2014.

11. Hristov, K., S. Radanski, R. Pepovich et al.. Changes in the composition and some physicochemical parameters of goat milk in subclinical mastitis and their diagnostic significance, Bulgarian Journal of Animal Husbandry, LII, 6; 13 -16, 2015

12. Kalin Hristov, Teodora Popova, Roman Pepovich et al., Characterization of Microbial Causative Agents of Subclinical Mastitis in Goats in Bulgaria, Int.J.Curr. Microbiol.App.Sci, 5(8): 316-323, 2016.

13. Larsen, T. and K. Aulrich, Optimizing the fluorometric $\beta$-Glucuronidaseassay in ruminant milk for more precise determination. J. Dairy Res.79:7-15, 2012.

14. Leitner, G., Merin, U., Silanikove et al., Effect of subclinical intramammary infection on somatic cell counts, NAGase activity and gross composition of goats' milk. J. Dairy Res. 71, 311-315, 2004

15. Maisi P., Riipinen I., Use of California Mastitis Test, N-Acetyl-Beta-Gluco $\neg$ saminidase, and Antitrypsin to diagnose caprine subclinical mastitis. J Dairy Res 55:309-314, 1988

16. Maisi, P., Milk NAGase, CMT and antitrypsin as indicators of caprine subclinical mastitis infections. Small Rumin. Res. 3, 493-501, 1990.

17. McDougall S., Supré K., Vliegher S. D., et al. Diagnosis and treatment of subclinical mastitis in early lactation in dairy goats. J Dairy Sci 93:4710-4721, 2010

18. Oliszewski R., Kairuz M.S.N., Elias S.N.G et al., Assessment of beta-glu-curonidase levels in goat's milk as an indicator of mastitis : comparison with other mastitis detection methods. J Food Protect 65:864-866, 2002

19. Park Y. W., Inter relationships between somatic cell counts, electrical conductivity, bacteria counts, percent fat and protein in goat milk. Small Rumin Re. 5:367-375. 1991. 
20. Pierce A., Legrand D., Advances in lactoferrin research. Biochimie, 91: 1-2, 2009

21. Schaeren W., Maurer J., Prevalence of subclinical udder infections and in 7 dividual somatic cell counts in three dairy goat herds during a full lactation. Schweiz Arch Tierh 148:641-648, 2006

22. Schüppel H., Schwope M., Zum Gehalt somatischer Zellen und zur mi-akrobiologischen Beschaffenheit der Milch von Ziegen mit klinisch unauffäl-ligem Euterbefund. Milchwissensch 54:13-16, 1999

23. Souza G., Brito J.R.F., Aparecida M., Brito V.P., Lange C., Faria C., Moraes L., Fonseca R.G., Silva Y., Composition and bulk somatic cell counts of milk from dairy goat herds in Southeastern Brazil. Braz J Vet Res Anim Sci 46:19-24, 2009

24. Van der Strate B.W.A., Beljaars L., Molema G et al.. Antiviral activities of lactoferrin. Antiviral Research, 52: 225- 239, 2001

25. Vasiu C., Bogolin I., Bolfa P., Relation between the geometrical mean of somatic cells from bulk milk and the prevalence of subclinical intramam $\neg$ mary infections in sheep and goats. Bulletin USAMV Veterinary Medicine 65:339-344, 2008

26. Vihan V. S., Determination of Na-gase activity in milk for diagnosis of sub-clinical Caprine mastitis. Small Rumin Res 2:359-366, 1989

27. Wilson D. J., Stewart K. N., Sears P. M., Effects of stage of lactation, produc $\neg$ tion, parity and season on somatic-cell counts in infected and uninfected dairy goats. Small Rumin Res 16:165169, 1995

\section{Corresponding author:}

Dimiter Dimitrov, DVM, PhD

Faculty of Veterinary Medicine, University of Forestry,

"Kliment Ohridsky" str.,10

1756, Sofia, Bulgaria.

email: mitko_3d@hotmail.com 